\title{
Dystonia as a Presenting Feature of Acute Ischemic Stroke: A Case Report and Literature Review
}

\author{
Yoram A. Roman Casul ${ }^{1}$, Meghan L. Humbert ${ }^{1}$, Amreen Farooqui ${ }^{1}$, Aparna Wagle Shukla ${ }^{1}$, Nandakumar \\ Nagaraja ${ }^{1}$ \\ 1. Department of Neurology, University of Florida College of Medicine, Gainesville, USA
}

Corresponding author: Nandakumar Nagaraja, nandakumar.nagaraja@neurology.ufl.edu

\begin{abstract}
Hypokinetic and hyperkinetic movement disorders can occur post-stroke. Of these, dystonia is known to occur in the chronic stage of stroke. Rarely, acute dystonia can present as a symptom of acute ischemic stroke or develop during hospitalization for ischemic stroke. In this article, we present a case of acute focal dystonia as a presenting symptom of acute ischemic stroke, review the literature to summarize previous reports, and provide more insight into the pathophysiologic mechanisms related to this presentation.
\end{abstract}

Categories: Neurology

Keywords: acute ischemic stroke, stroke, acute dystonia, dystonia, focal dystonia

\section{Introduction}

Dystonia is an abnormal involuntary movement consisting of sustained muscle contraction that frequently appears as abnormal posturing or twisting and repetitive movements. Dystonia is the second most observed phenotype of post-stroke dyskinesias representing around $20 \%$ of cases [1]. The other two phenotypes are choreiform dyskinesias (athetosis, ballism, chorea) and non-chorea-dystonic dyskinesias (myoclonus, asterixis, tremor) [2]. Post-stroke dyskinesias can vary in onset after acute stroke and length of course depending on the type. Nearly $50 \%$ of hemidystonia is accounted for by stroke which is the cause of most hemidystonia onset after the age of 50 [2]. Post-stroke dystonias tend to have a delayed onset ranging between three months and three years with an average of 9.5 months [2], while some have reported onset as early as day one of stroke [2,3]. In contrast, hemichorea can develop within just a few days (4.3 days on average) following a stroke. Prognosis varies depending on the location which can be cortical or basal ganglia including subthalamic nuclei [2,3]. Thus, dystonia as a presentation of acute ischemic stroke (AIS) is uncommon. Here, we present a case of acute focal dystonia as a presenting symptom of AIS, review the literature to summarize previous reports, and provide further insight into the pathophysiologic mechanisms related to this presentation.

Review began 08/03/2021 Review ended 08/11/2021 Published 08/18/2021

\section{Copyright 2021}

Roman Casul et al. This is an open access article distributed under the terms of the Creative Commons Attribution License CC-BY 4.0., which permits unrestricted use, distribution, and reproduction in any medium, provided the original author and source are credited.

\section{Case Presentation}

A 52-year-old woman with a past medical history of uncontrolled type II diabetes mellitus presented with right upper extremity weakness of one-hour duration. While communicating with the emergency department team, the patient had an episode of spontaneous painful posturing with rotation and flexion of the right arm and extension of the right leg that resolved in less than a minute without intervention. During evaluation by the stroke team, she had another episode of similar painful posturing. The National Institutes of Health Stroke Scale score was 2 for right upper extremity ataxia and dysarthria. She had mild weakness of the right wrist extensors without any right arm drift. Blood pressure on admission was 202/99 $\mathrm{mmHg}$ and blood glucose level was $358 \mathrm{mg} / \mathrm{dL}$. CT head did not show acute hemorrhage or notable hypodensity. CT angiogram of the head and neck showed multifocal intracranial atherosclerosis particularly in the left middle cerebral artery and internal carotid artery. CT perfusion showed the increased time to peak involving the left posterior frontal lobe, parietal lobe, and posterior temporal lobe (Figure 1). Thrombolysis was done using intravenous alteplase. MRI brain showed small embolic strokes in the left primary motor and supplementary motor area (Figure 1) and a small lesion in the left parietal cortex. Stroke workup was remarkable for positive urine drug toxicology for cocaine, apical akinesia of left ventricle on transthoracic echocardiogram, hemoglobin A1c of 16.7\%, total cholesterol of $378 \mathrm{mg} / \mathrm{dL}$, high-density lipoprotein of 35 $\mathrm{mg} / \mathrm{dL}$, triglycerides of $422 \mathrm{~mm} / \mathrm{dL}$, and incalculable low-density lipoprotein. Stroke was determined to have two or more etiologies, namely, left middle cerebral artery stenosis, apical akinesia of left ventricle, and cocaine use. The patient was started on dual antiplatelet therapy and statin for secondary stroke prevention. She did not have further dystonia episodes during admission and was discharged home without any complications. 


\section{Cureus}

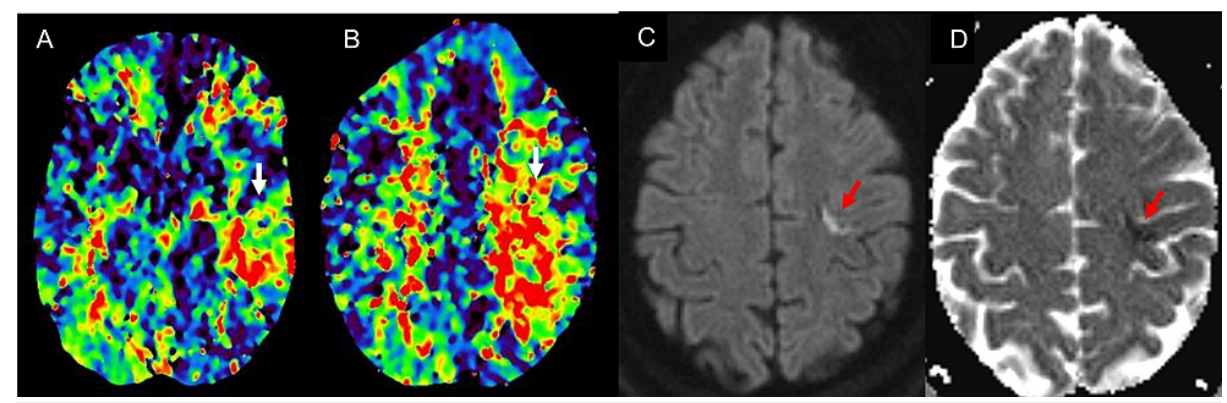

FIGURE 1: Increased time to peak (A, B) in the left posterior frontal, parietal, and temporal lobe; ischemic stroke on diffusion-weighted imaging (C); and apparent diffusion coefficient (D) in the left primary motor and supplementary motor cortex.

\section{Discussion}

A systematic review was performed in compliance with the Preferred Reporting Items for Systematic Reviews and Meta-Analysis (PRISMA) statement [4]. A comprehensive search of the PubMed database was performed on March 14, 2021. The main keywords used in the search were "acute stroke, stroke, acute dystonic seizure, dystonia, acute dystonia." All articles in PubMed from its inception were included in the search. The reference list of the articles that met the eligibility criteria was reviewed.

The inclusion criteria for the selection of articles were: (1) patient had a primary diagnosis of AIS, (2) patient presented with acute episodic dystonic movement or had dystonia during hospitalization for AIS, (3) there was a detailed description of the case along with supporting evidence related to the diagnosis. The exclusion criteria for the articles were: (1) presence of intracerebral hemorrhage on CT, (2) insufficient data supporting movement disorder as a presenting symptom in the acute phase, (3) dystonia occurring as a delayed manifestation more than one week after stroke onset.

Two authors (NN and YR) screened the titles and abstracts to identify articles relevant to the study. The selected articles were reviewed in detail (by MH) to extract relevant data using a data extraction form that included variables for demographics, clinical presentation, stroke location, stroke etiology, treatment received, and outcomes.

A total of 635 articles were reviewed from PubMed with the study search terms. Among them, nine articles met the study criteria. There was a total of nine cases of acute dystonia presenting as AIS. Figure 2 shows the flow diagram of several articles identified and those included in the review. Cases were grouped in those presenting with (1) cortical lesions including those involving supplementary motor area (SMA) and premotor cortex, (2) subcortical lesions such as the thalamus and basal ganglia, and (3) brainstem (midbrain, pons, and medulla) and cerebellar lesions (Table 1).

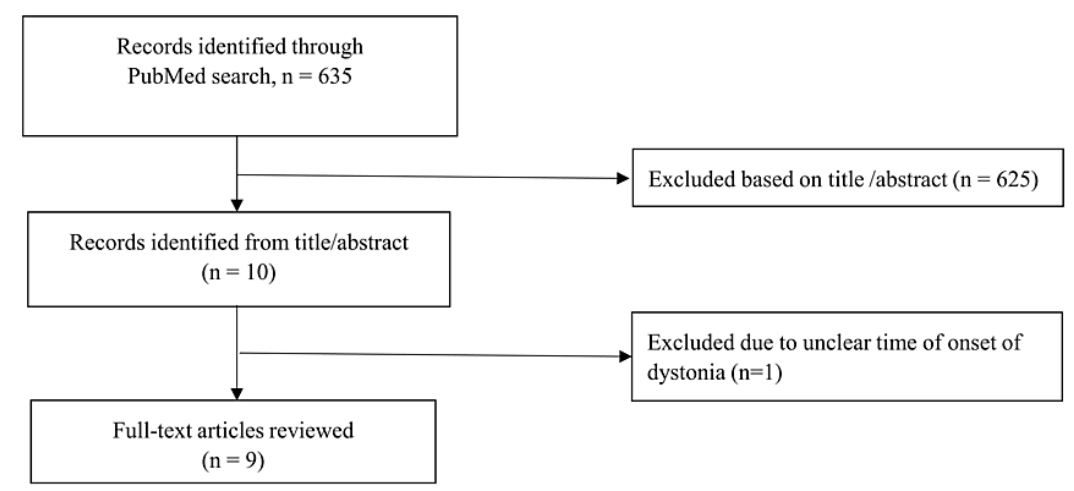

FIGURE 2: PRISMA flowchart.

PRISMA: Preferred Reporting Items for Systematic Reviews and Meta-Analysis 


\section{Cureus}

\begin{tabular}{|c|c|c|c|c|c|}
\hline $\begin{array}{l}\text { Author, } \\
\text { year }\end{array}$ & $\begin{array}{l}\text { Age, } \\
\text { gender }\end{array}$ & Clinical presentation & Stroke location & Stroke etiology & Treatment/Outcome \\
\hline $\begin{array}{l}\text { Dhakar et } \\
\text { al., } 2015 \\
\text { [5] }\end{array}$ & $63, \mathrm{~F}$ & $\begin{array}{l}\text { Presented with sudden-onset left upper extremity } \\
\text { stiffness. Sustained muscle contractions causing } \\
\text { flexion at the elbow, wrist, and fingers; left facial } \\
\text { upper motor neuron weakness; and left lower } \\
\text { extremity weakness without an increase in tone }\end{array}$ & $\begin{array}{l}\text { Right premotor } \\
\text { cortex and } \\
\text { supplementary } \\
\text { motor area }\end{array}$ & $\begin{array}{l}\text { Intracranial } \\
\text { atherosclerosis }\end{array}$ & $\begin{array}{l}\text { Discharged to rehab, } \\
\text { gradual } \\
\text { improvement of } \\
\text { dystonia }\end{array}$ \\
\hline $\begin{array}{l}\text { Nishimura } \\
\text { et al., } \\
2014 \text { [6] }\end{array}$ & $63, \mathrm{M}$ & $\begin{array}{l}\text { Presented with the stiffness of left limbs, } \\
\text { dysarthria, and left central facial palsy. On day } 2 \text {, } \\
\text { the patient developed dystonic posture of the left } \\
\text { upper extremity }\end{array}$ & $\begin{array}{l}\text { Right } \\
\text { supplementary } \\
\text { motor area and } \\
\text { left precentral } \\
\text { gyrus }\end{array}$ & $\begin{array}{l}\text { Left internal } \\
\text { carotid artery } \\
\text { occlusion at its } \\
\text { origin }\end{array}$ & $\begin{array}{l}\text { Dystonia improved } \\
\text { spontaneously }\end{array}$ \\
\hline $\begin{array}{l}\text { Miletić et } \\
\text { al, } 2015 \\
{[7]}\end{array}$ & $71, F$ & $\begin{array}{l}\text { Presented with right hemiparesis and right } \\
\text { supranuclear facial palsy that started } 5 \text { hours prior } \\
\text { to admission. Hemidystonia in the right upper } \\
\text { extremity occurred } 18 \text { hours after stroke onset }\end{array}$ & $\begin{array}{l}\text { Left frontal } \\
\text { cortical region }\end{array}$ & $\begin{array}{l}\text { Cardioembolic } \\
\text { (atrial fibrillation) }\end{array}$ & Haloperidol \\
\hline $\begin{array}{l}\text { Sabrie et } \\
\text { al., } 2015 \\
{[8]}\end{array}$ & $25, \mathrm{M}$ & $\begin{array}{l}\text { Presented with left-sided hemiparesis, left-sided } \\
\text { hypoesthesia with proprioceptive dysfunction, and } \\
\text { left homonymous hemianopsia. Developed } \\
\text { dystonia in his left arm on day } 2 \text { of stroke }\end{array}$ & $\begin{array}{l}\text { Right thalamus } \\
\text { and medial } \\
\text { temporal lobe }\end{array}$ & $\begin{array}{l}\text { Patent foramen } \\
\text { ovale and } \\
\text { antiphospholipid } \\
\text { antibodies }\end{array}$ & $\begin{array}{l}\text { Clonazepam } \\
\text { (unsuccessful) } \\
\text { followed by } \\
\text { carbamazepine }\end{array}$ \\
\hline $\begin{array}{l}\text { Choi et } \\
\text { al., } 2015 \\
\text { [9] }\end{array}$ & $66, \mathrm{M}$ & $\begin{array}{l}\text { Presented with a 3-week history of gait } \\
\text { disturbance, difficulty writing, dysphagia, and } \\
\text { dysarthria. On examination, the patient had } \\
\text { multifocal dystonia in bilateral hands and feet as } \\
\text { well as tongue contractions, bilateral ataxia in the } \\
\text { upper and lower extremities, and wide-based gait }\end{array}$ & Right midbrain & $\begin{array}{l}\text { Small-vessel } \\
\text { disease }\end{array}$ & $\begin{array}{l}\text { Clonazepam and } \\
\text { trihexyphenidyl (no } \\
\text { improvement) }\end{array}$ \\
\hline $\begin{array}{l}\text { Kim et al., } \\
2009 \text { [10] }\end{array}$ & $56, \mathrm{M}$ & $\begin{array}{l}\text { Presented with headache, left hemiparesis, and } \\
\text { dysarthria. On day } 4 \text {, the patient developed } \\
\text { dystonia in the form of left wrist sustaining } \\
\text { choreiform movements, along with posturing of the } \\
\text { arm }\end{array}$ & $\begin{array}{l}\text { Right midbrain } \\
\text { lesion with } \\
\text { extension into } \\
\text { the substantia } \\
\text { nigra and } \\
\text { subthalamic } \\
\text { nucleus }\end{array}$ & $\begin{array}{l}\text { Small-vessel } \\
\text { disease }\end{array}$ & $\begin{array}{l}\text { Unsuccessful trials } \\
\text { of tetrabenazine, } \\
\text { haloperidol, } \\
\text { orphenadrine, and } \\
\text { botulinum toxin. } \\
\text { Eventually went for } \\
\text { deep brain } \\
\text { stimulation surgery }\end{array}$ \\
\hline $\begin{array}{l}\text { Tan et al., } \\
2005 \text { [11] }\end{array}$ & $43, \mathrm{M}$ & $\begin{array}{l}\text { Presented with sudden-onset weakness and } \\
\text { spasms of right hemibody, dysarthria, and mild } \\
\text { right facial upper motor nerve palsy. Within hours } \\
\text { of his initial presentation, he developed pain and } \\
\text { spasms in his right upper and lower extremities }\end{array}$ & $\begin{array}{l}\text { Left } \\
\text { paramedian } \\
\text { and ventral } \\
\text { pons }\end{array}$ & $\begin{array}{l}\text { Intracranial } \\
\text { atherosclerosis }\end{array}$ & $\begin{array}{l}\text { Clonazepam. Mild } \\
\text { dystonia was } \\
\text { observed at 1-year } \\
\text { follow-up }\end{array}$ \\
\hline $\begin{array}{l}\text { Ogawa et } \\
\text { al., } 2018 \\
{[12]}\end{array}$ & $86, F$ & $\begin{array}{l}\text { Presented with weakness in the left upper and } \\
\text { lower extremities, numbness of the right upper and } \\
\text { lower extremities, and dysarthria. Several days } \\
\text { following stroke, the patient demonstrated cervico- } \\
\text { shoulder dystonia }\end{array}$ & $\begin{array}{l}\text { Left lateral } \\
\text { medullary } \\
\text { infarction }\end{array}$ & $\begin{array}{l}\text { Left vertebral } \\
\text { artery occlusion }\end{array}$ & N/A \\
\hline $\begin{array}{l}\text { Zadro et } \\
\text { al, 2008 } \\
{[13]}\end{array}$ & $48, F$ & $\begin{array}{l}\text { Sudden-onset vertigo, vomiting, and ataxia. } \\
\text { Horizontal, bidirectional nystagmus and ataxia of } \\
\text { the left limbs. On day } 2 \text { of admission, the patient } \\
\text { developed abnormal movement of the head with } \\
\text { spasm of the cervical muscles }\end{array}$ & $\begin{array}{l}\text { Left cerebellar } \\
\text { infarction }\end{array}$ & Undetermined & $\begin{array}{l}\text { Clonazepam and } \\
\text { baclofen }\end{array}$ \\
\hline
\end{tabular}

TABLE 1: Clinical characteristics of acute dystonia in acute ischemic stroke. 
spontaneously without any acute intervention. Another patient presented with right hemiparesis and subsequently developed dystonia 18 hours after onset secondary to left frontal cortical ischemic stroke due to cardioembolic etiology [7]. The patient was started on haloperidol during admission for treatment of his dystonia. Two out of these three cases had facial, upper, and lower extremity paresis in addition to dystonia.

Subcortical structure such as the thalamus was involved in one patient who presented with left-sided weakness and acute dystonia on day two of stroke secondary to antiphospholipid syndrome and patent foramen ovale [8]. This patient was initially started on clonazepam without improvement and later transitioned to carbamazepine.

Although unexpected, there were cases of acute dystonia presenting as ischemic strokes involving brainstem structures. Of the five cases, two had strokes in the midbrain $[9,10]$, and one each had strokes in the pons [11], medulla [12], and cerebellum [13]. Of particular interest was a 56-year-old male who was noted to have dystonic posturing on his left wrist four days after initial presentation with left-sided weakness and dysarthria. This patient also had involvement of substantial nigra and subthalamic nucleus supporting the idea of the dystonic phenomenon being secondary to disruption of motor pathways [10]. The patient's dystonia was also very difficult to control requiring numerous medications without success and eventually needing deep brain stimulation as treatment [10]. One patient with cerebellar infarction who presented with vertigo, vomiting, nystagmus, and ataxia later developed cervical dystonia. There was a slight improvement in the patient's condition with clonazepam and baclofen and a significant improvement with botox treatment a month later [13].

Post-stroke movement disorders can be either hypo or hyperkinetic, with post-stroke dyskinesias (involuntary hyperkinetic movements) the more common of the two to present in the first year following a stroke [1]. The prevalence of hyperkinetic movement disorders is uncommon, with some studies reporting a prevalence of about $1 \%(29 / 2,500)$ with an incidence of $0.08 \%$ per year [14]. A large portion of those with basal ganglia lesions did not result in movement disorders, which supports the rarity of post-stroke movement disorders and highlights that location is not predictive of whether patients will have movement disorders after stroke [14]. Dystonia and other types of abnormal involuntary movements such as chorea, tremors, and parkinsonism are commonly associated with both ischemic and hemorrhagic strokes [15].

Dystonia is a network disorder involving the motor cortex, where motor commands are generated, and the basal ganglia and cerebellum, where these are further refined to allow for smoother and more coordinated movements. There exists a balance between inhibitory and excitatory pathways. The "direct pathway" is the excitatory pathway resulting from the disinhibition of upper motor neurons via connections from the caudate and putamen to the globus pallidus internal segment and substantia nigra. The "indirect pathway" is responsible for modulating disinhibition of the direct pathway (a sort of check feature), and the net result is the activation of the indirect pathway that leads to inhibition of the upper motor neurons [16]. Although stroke-related dyskinesia pathogenesis is not yet completely understood, some suggestions include postsynaptic denervation hypersensitivity as well as impaired plasticity of axons and dendrites after an ischemic injury [1]. While rare, they can occur at any point in the motor circuitry. No one location in this pathway is a reliable predictor of if or which particular dyskinesia will arise, and hence, stroke-related movement disorders are not easy to predict based on stroke anatomical characteristics alone [1].

The most common site of isolated lesions causing dystonia is the putamen but the thalamus, pallidum, caudate, and midbrain have also been implicated [2]. The suggestion is to interrupt the connections between the basal ganglia, specifically to the sensorimotor part of the putamen, striatum, and pallidum, which increases thalamic drive projecting to frontal and motor cortical areas resulting in dystonia [2,17]. Other studies also support that hyperkinetic movements following stroke result from thalamic disinhibition, which, in turn, releases the motor cortex in the indirect pathway; a similar result is seen from overactivity of the direct pathway [1]. Efferent projections from the SMA to the putamen, caudate nucleus, and subthalamus likely contribute to spreading signals and dystonic symptoms [18]. In our study, only one patient who had dystonia in AIS had a lesion in the thalamus. Whereas the thalamus and basal ganglia are common sites implicated for delayed-onset dystonia, commonly seen post-stroke, they may be less likely involved in the acute presentation of dystonia in AIS.

It could be challenging to determine if a patient presents with isolated acute dystonia or a symptom of AIS. Based on our case and previous case reports, if a patient has any associated neurological symptoms such as weakness in the extremities, facial droop, or dysarthria, it should raise the possibility of AIS and should be considered in the differential diagnosis. Screening for thrombolytics should be considered if they are in the 0-4.5-hour treatment window. The presence of perfusion deficit on CT perfusion scan could suggest that it is an AIS rather than isolated dystonia, as in our case.

Our study had limitations. The review was limited to a literature search involving the PubMed database. Our study focused on AIS. Patients with intracerebral hemorrhages were excluded. We also focused on articles that described dystonia as a presenting symptom of stroke or that developed during hospitalization. Articles that reported dystonia as a chronic effect of stroke or those that did not describe the timing of dystonia in relation to stroke onset were excluded. 


\section{Conclusions}

Although not a common presentation, acute dystonia can be a presenting symptom of AIS. It occurs in stroke involving the frontal lobe and brainstem structures and is probably less likely from stroke involving the deep subcortical structures. In patients presenting with acute dystonia, particularly with associated symptoms such as weakness in the extremities, AIS should be considered in the differential diagnosis, and they should be screened for thrombolytics if they are in the treatment window.

\section{Additional Information}

\section{Disclosures}

Human subjects: Consent was obtained or waived by all participants in this study. Conflicts of interest: In compliance with the ICMJE uniform disclosure form, all authors declare the following: Payment/services info: All authors have declared that no financial support was received from any organization for the submitted work. Financial relationships: All authors have declared that they have no financial relationships at present or within the previous three years with any organizations that might have an interest in the submitted work. Other relationships: All authors have declared that there are no other relationships or activities that could appear to have influenced the submitted work.

\section{References}

1. Nakawah MO, Lai EC: Post-stroke dyskinesias. Neuropsychiatr Dis Treat. 2016, 12:2885-93. 10.2147/NDT.S118347

2. Bansil S, Prakash N, Kaye J, Wrigley S, Manata C, Stevens-Haas C, Kurlan R: Movement disorders after stroke in adults: a review. Tremor Other Hyperkinet Mov (N Y). 2012, 2: 10.7916/D86W98TB

3. Siniscalchi A, Gallelli L, Labate A, Malferrari G, Palleria C, Sarro GD: Post-stroke movement disorders: clinical manifestations and pharmacological management. Curr Neuropharmacol. 2012, 10:254-62. 10.2174/157015912803217341

4. Moher D, Liberati A, Tetzlaff J, Altman DG: Preferred reporting items for systematic reviews and metaanalyses: the PRISMA statement. PLoS Med. 2009, 6:e1000097. 10.1371/journal.pmed.1000097

5. Dhakar MB, Watson C, Rajamani K: Acute onset dystonia after infarction of premotor and supplementary motor cortex. J Stroke Cerebrovasc Dis. 2015, 24:2880-2. 10.1016/j.jstrokecerebrovasdis.2015.09.016

6. Nishimura K, Uehara T, Toyoda K: Early-onset dystonia after supplementary motor area infarction. J Stroke Cerebrovasc Dis. 2014, 23:1267-8. 10.1016/j.jstrokecerebrovasdis.2013.09.028

7. Miletić V, Blažina K: Hemidystonia caused by frontal cortical infarction . Acta Neurol Belg. 2015, 115:383-4. 10.1007/s13760-014-0354-3

8. Sabrie M, Berhoune N, Nighoghossian N: Alien hand syndrome and paroxystic dystonia after right posterior cerebral artery territory infarction. Neurol Sci. 2015, 36:1709-10. 10.1007/s10072-015-2243-9

9. Choi HY, Jung YJ, Shin HW: Multifocal dystonia as a manifestation of acute midbrain infarction . J Neurol Sci. 2015, 356:217-8. 10.1016/j.jns.2015.06.068

10. Kim HJ, Lee MC, Kim JS, Chung SJ, Kim HJ, Kwon M, Shin HW: Lingual dystonia as a manifestation of thalamic infarction. Mov Disord. 2009, 24:1703-4. 10.1002/mds.22657

11. Tan EK, Chan LL, Auchus AP: Hemidystonia precipitated by acute pontine infarct. J Neurol Sci. 2005, 234:109-11. 10.1016/j.jns.2005.03.046

12. Ogawa T, Shojima Y, Kuroki T, Eguchi H, Hattori N, Miwa H: Cervico-shoulder dystonia following lateral medullary infarction: a case report and review of the literature. J Med Case Rep. 2018, 12:34. 10.1186/s13256-018-1561-y

13. Zadro I, Brinar VV, Barun B, Ozretić D, Habek M: Cervical dystonia due to cerebellar stroke. Mov Disord. 2008, 23:919-20. 10.1002/mds.21981

14. Ghika-Schmid F, Ghika J, Regli F, Bogousslavsky J: Hyperkinetic movement disorders during and after acute stroke: the Lausanne Stroke Registry. J Neurol Sci. 1997, 146:109-16. 10.1016/s0022-510x(96)00290-0

15. Alarcón F, Zijlmans JC, Dueñas G, Cevallos N: Post-stroke movement disorders: report of 56 patients. J Neurol Neurosurg Psychiatry. 2004, 75:1568-74. 10.1136/jnnp.2003.011874

16. Purves D, Augustine GJ, Fitzpatrick D, et al.: Circuits within the basal ganglia system. Neuroscience. Purves D, Augustine GJ, Fitzpatrick D, et al. (ed): Sinauer Associates, Sunderland, MA; 2001.

17. Goldberg JH, Farries MA, Fee MS: Basal ganglia output to the thalamus: still a paradox . Trends Neurosci. 2013, 36:695-705. 10.1016/j.tins.2013.09.001

18. Jürgens U: The efferent and afferent connections of the supplementary motor area . Brain Res. 1984, 300:6381. 10.1016/0006-8993(84)91341-6 